(181)

\title{
An assessment on Trends of Exportation of Forest Products in Sri Lanka
}

\author{
M.A.C. Lakmini* , U.A.D.P. Gunawardena \\ ${ }^{I}$ Department of Forestry and Environmental Science, University of Sri Jayewardenepura, Sri Lanka \\ "maclakmini@yahoo.com
}

\begin{abstract}
The resources extracted directly from forest or forest based sources are defined as forest products. Sources of such produce include various forest types which belong to state (montane, submontane, lowland rain, moist monsoon, dry monsoon, savanah and mangroves) and home gardens. Export forest products are of three main categories: significant non-wood forest products which are medicinal plants, rattans, bamboo, edible plants, gums and resins, and moderately significant non-wood forest product exports which are Kithul produce, barks, fruits, seeds, flowers, and leaves from forest and wood products. Quantification of exported forest products have however received lesser attention and the objectives of this study are therefore to prepare an inventory of exported forest products of Sri Lanka with types, quantities, values and destinations and to identify the trends of exports.
\end{abstract}

Data were collected from Forest Department and Sri Lanka Customs. Forest Department issues export permits for different product types of plant parts, wood and non-wood value added products. Details related to product types, quantities, values and destinations have been extracted from the records and analysed for the last five years. Major product markets were also identified by analyzing the obtained data.

Results indicate that there are about 2,400 permits issued per year for both wood products exports and plants/plant material exports. Quantity of the wood products exports per year are about 5million pieces. Seventy five percent was for commercial purposes and $24.43 \%$ was for individual requirements. The major exports markets were United Kingdom, Australia, India and Maldives. Quantity of the plants/plant material exports per year are about 6.3 million pieces. About $91.9 \%$ is for commercial purpose and $8.1 \%$ is for individual requirements. The major export markets were Germany, Kuwait, Japan and Netherland.

Records of the Sri Lanka Customs showed that there are significant illegal exports including Wallapatta, Sandalwood, live plants, cardamom, orchid plants and bird nests. Common export restrictions of Forest Department include plants and plant parts such as Kothalahibutu (Salaciareticulata), Nux vomica, Polpala, Kottamba leaves (Terminalia catappa) and Maswadda.

Implications for policy include mechanisms to formalise record keeping procedures of the institutions involved and the urgent measures to avoid the significant losses to the economy due to illegal exports.

Keywords: Forest products, Legal/illegal exports, Wood and non-wood forest products, Economy 